\title{
FAMINE AND AFFORESTATION IN CHINA
}

By PROFESSOR JOSEPH BAILIE

I BAD been in China less than two years when, in the winter of 1891, one of the famines in the districts north of Soochow, where I was then stationed, came on. Our mission station, which is outside of the north-west gate of the city, is on the Grand Canal. Close to our front gate there was one of the dumping grounds for the famine refugees, which were placed at points along the Grand Canal. When refugees desired to go to a considerable distance from the famine district, they used to form themselves into bands of several hundreds and sometimes of thousands, with some head men in charge. These head men would go to the Yamen and demand help. The official would give so many cash per head and then commandeer all the boats in the vicinity, pack all the gang on to these boats and send them as speedily as possible along the canal to the jurisdiction of the next magistrate where they were dumped; he in turn followed the same tactics as his predecessor. At each dumping place refugees would leak out and shift for themselves, so that after going one or two hundred miles the thousands melted away among the towns and villages along the line of the canal and became beggars or workmen or thugs according to their bent.

Living at our mission compound so close to the source of these famines, we witnessed scenes that never can be erased from our memories. Mothers, themselves nearly naked, having their naked infants lying in their bosoms beneath the rags intended to cover them in order to impart what heat they could to their offspring, dragged themselves 
along through snow and sleet or fell down along the roadside to be laid to rest in the potter's field. There we were, placed as missionaries with just enough allowance to give us and our children subsistence, where we were compelled to witness all this yet not having the wherewithal to relieve the suffering. What a hell it was to be able only to go out in the midst of such a crowd and talk of the love of God to people desperate with hunger and cold. In desperation I went and changed a few dollars into cents and attempted to distribute the money, but several of the crowd set upon me to get all that was in the bag. I ran, taking the coppers out in handfuls and throwing them on all sides, but before I could get half of what I had distributed in this way I was cornered, my bag wrenched from my grasp and my clothes almost torn to pieces before I could extricate myself from the hungry wolves. That was my first and last attempt to alleviate suffering in this manner.

Nearly twenty years later, in the famine of 1910-1, there were in and around Nanking over one hundred thousand famine refugees. Any attempt to describe the misery of these poor creatures huddled together under straw mats put up as shelters in vacant places fails. It is impossible to convey by words any idea of what famine in China means. One has to wade through the filth in which these colonies of refugees are settled and bend down and creep into some of the huts and breathe the putrid air, see those dying of famine fever and hear the weak lamentations of mothers and children squatting around the dead body of the father, the bread-winner of the family, or the quiet grief of the husband before the still form of the mother of his little orphans, before one can realize what are the horrors of famine and pestilence.

Among other institutions attempting to relieve the distress in Nanking city at this time, the Chung Ren Tang (Guild of Mercy) fed or rather distributed rice gruel to a crowd of twenty thousand starving people every day. Never will that sight leave my eyes : men, women and 
children penned into the alleys of the now unused old examination halls; soldiers with heavy bamboo sticks driving crowds from one shed to another, reminding one of herding cattle for branding; guards standing at the end of each alley, preventing a rush being made on the men who were ladling out food to the single file coming out of each of these lanes, some of those who received their alms pouring it into their mouths as they were hastened to the outer gate.

After being led through the crowds by a guard of soldiers I was brought to the rows of big $k$ 'angs for holding the rice porridge. After finding out that $\mathrm{Mr}$ Chang was at the head of this organization $I$ requested to be led to his place. On meeting the fine old man I complimented him on the good work he was doing, and then asked what steps were being taken to avert another such disaster. He shrugged his shoulders and said that that must be done by the officials as no private person dare attempt any such thing. I suggested that if the money being spent in giving rice were used in paying the people for breaking up and planting the unused lands outside the city, the lands thus improved could be given to some of these refugees who had no lands, and in that way several hundred families could be put beyond want permanently. Besides this, the thousands then huddled in the filthy places of the city could be stationed out on the mountainside where they would have fresh air while the typhus fever epidemic was raging in the city.

Mr Chang said he was powerless to secure even these waste lands for this purpose. After nearly three years' fight we not only obtained those very lands for this purpose, but also enlisted the leading men of Nanking city, who were our opponents at first, to become the Nanking branch of the Colonization Association of the Republic of China. The head of the Nanking gentry is the president of the Nanking branch and Mr Wei Chia Hua is our treasurer. He is a Hanlin (i.e., the highest degree conferred under the old 
system), and reckoned a saint by the Chinese. He has been made commissioner for famine relief work on several occasions and is still a poor man.

The work done outside Nanking city by our society in building roads and reclaiming and afforesting Purple Mountain so pleased the Minister of Agriculture and Commerce that he appointed our estate the official forest demonstration station for the province of Kiangsu. This was done in a speech he made on the station itself on the occasion when he and Consul Williams, representing the American Minister, Dr Reinach, planted trees in commemoration of the opening of our School of Forestry in the University of Nanking. This was the first official treeplanting in the history of China, and on that day Arbor Day was established for the whole nation. Thus our attempts at helping the poor have brought forth fruit in not only opening up colonies where the destitute are being put on to the vacant lands, but in the establishment of our college of agriculture and forestry and in the establishment of Arbor Day. Arbor Day has proved to be no unreal name, for in the year 1916 on Ching Ming, the Chinese Easter festival, tens of thousands of trees were planted by school children and the military all over the country. There is thus a sentiment being created which, if fostered for a few decades, will convert the naked mountains of China into a valuable asset in the form of forests.

Mast of the lands we have so far been able to acquire for this colonization work have been mountainous, and only the valleys and level places are fit for cultivation. The untilled hillsides are being planted, and the farmers hold the lands they till by taking care of the forests planted in the immediate vicinity of their lands instead of paying rent. This we call the Forest Colony. By means of it large numbers of people are given work during the winter and spring months, when tree-planting can be done. But to supervise these thousands of workmen means the training of a number of young foresters, and this is why our School of Forestry 
was opened. The Minister of Agriculture, preferring this practical way of training foresters to the theoretical manner in which they were being taught in a school opened some time previously by his department, shut up his own school and sent twenty-four of the best students to us, giving us a yearly grant of $\$ \mathbf{8 0 0 0}$. This, with the fees of the scholarship students sent by the Minister and the provincial governors, realized the sum of about $\$ 12,000$ Mexican. This of course falls far short of supplying money enough to pay all the expenses involved in running a school of forestry, and it is hoped that the new government will see its way to putting us in such a financial position as will leave us no longer burdened with anxiety as to whether we can secure salaries for competent men as teachers.

At Laian-hsien we had a hard fight to start this colonization work. In 1910 we took up seven families to begin work on a patch of land that had been given by the father of two of our students. We had worked only ten days when this man was summoned by the official to appear at the Yamen and answer the charge of giving the Emperor's lands to a foreigner. The poor man came to me pale and trembling, knowing that this meant his destruction. I called the people off the land, sold our implements to any one that wanted them and returned to Nanking. But in less than two years we had a petition from all the gentry in that same district requesting us to return and open a colony. We formed a branch colony, surveyed and mapped 2000 acres of mountain lands which were made over by the magistrate to the Colonization Association, and now there are seventy-one families of $\mathbf{3 7 9}$ persons established on those lands and able to stand on their own feet. Each family had a guarantor of its character, who also promised to pay the money advanced to these poor people in case they failed to refund it themselves. When the money is returned we shall use it to put others on similar pieces of land.

We have thus proved to the Chinese government that these lands are fit for agriculture, that agricultural loans 


\section{Famine and Afforestation in China}

can easily be managed, and best of all, that beggars and robbers can be transformed into law-abiding citizens. We were told before we began that even if we succeeded in producing crops, the place was so infested with robbers that everything would be stolen from the colonists. So far not a chicken or sheaf of corn has been stolen. We have fed the robbers.

China at present is looking to us for help. We can supply what she needs. She needs men who will assist in developing her resources, and whether we co-operate or not she will finally secure men to do this. Who are these men to be and how are these resources to be developed? Are the leaders in industry to be men who grind the poor and prostitute the proceeds of industry to the propagation of vice, or use those resources to benefit the people socially and morally? Let me illustrate these two extremes. In the famine region in famine years the poor people sell their cattle, then their houses and children, and finally their lands for one tenth or one fiftieth of their value. Heartless tyrants grab these lands and rent them ever after for half the produce. If the year is good they ship off their big half of the produce and, being the type of men a great many of them are, frequent the immoral districts in Shanghai and other places. The poor farmers can live in good years, but when bad years come they have to sell their daughters to supply the very haunts frequented by their oppressors.

Now look at another picture. Three compositors in the Presbyterian Mission Press, one named Hsia and two named Bao, took it into their heads in the year 1891 to open a printing place of their own. They began in a little room of about twelve feet by twelve, doing their own work. This was the beginning of the Commercial Press, a firm that now sells about two million dollars' worth of its own printed material every year. The whole is conducted on Christian principles. Day schools are provided for the children of the employés and night schools for the employés themselves. No philanthropic cause in Shanghai lacks the 
support of the Commercial Press. Here is Christianity of the real leavening type.

A great many people objected that running a business concern like the Presbyterian Mission Press ought to be left for outsiders, and that the duty of the missionary was to preach the Gospel. But the printing business of China has now the stamp of Christianity upon it and its influence for good is incalculable. Can we not get hold of the other industries by selecting common-sense Christian tanners, hatmakers, dyers, spinners and others who will come out and live clean, honest lives as missionaries? It is not necessary to preach ; the whole life will be a sermon. To secure such men a sort of missionary information bureau should be established. The bureau ought to be composed of some Christian millowners, Christian workmen, Christian farmers, Christian heads of industries with some of their employés. It need not be a bureau for collecting money. Very little money is needed. China needs good experts to teach the people how to begin industries and China can pay them. We are all being asked to recommend men for this purpose. Can we not get men to go out to begin such industries who are not only excellent each in his own line but who will stamp their Christian characters on their employés? The bureau that could select and recommend clean men of such a type would do more to make the Church of Christ self-supporting in China than if they sent out hundreds of preachers. I do not wish to be misunderstood as depreciating the preaching of the gospel of Jesus Christ. But the complaint now is that the Chinese churches cannot support their pastors, and money has to be sent constantly from Great Britain and America for the purpose. If steel plants, spinning mills, weaving factories, tanneries, factories for making hats and other industrial enterprises were founded by men who felt their responsibilities to live in Christ, we would have the stamp of our Master put not only on the workmen but also on the capitalists.

Joseph BaILIE 